\title{
МІЖНАРОДНІ ЕКОЛОГІЧНІ ПРОЕКТИ КАФЕДРИ БОТАНІКИ ТА ЕКОЛОГІЇ КРИВОРІЗЬКОГО ДЕРЖАВНОГО ПЕДАГОГІЧНОГО УНІВЕРСИТЕТУ
}

\author{
Е. О. Євтушенко*, В. М. Савосько \\ Криворізъкий державний педагогічний університет, \\ м. Кривий Ріг, Україна
}

\begin{abstract}
Анотація. Мета роботи проаналізувати результати участі викладачів і співробітників кафедри ботаніки та екології Криворізького державного педагогічного університету у міжнародних екологічних проектах, які були реалізовані у XXI ст. Міжнародний науковий проект «Територія кар'єру як депозитарій для рідкісних рослин і основа для екологічної освіти» був виконаний в рамках програми The Quarry Life Award 2014 (організатор «HeidelbergCement»). Під час реалізації проекту його команда, основу якої складали викладачі і співробітники кафедри ботаніки та екології, на Жовтокам'янському кар'єрі здійснила наступне: 1) провела екологоландшафтний аналіз території, 2) дослідила фіторізноманіття, 3) створила депозитарій «Рослини Червоної книги», 4) розробила екологічну стежку «Зелений шлях», 5) запропонувала напрямки подальшого розвитку проекту.

Реалізація міжнародного наукового проекту «Створення чагарникових угруповань як нового місця існування для біоти кар'єру» в рамках програми The Quarry Life Award 2018 (організатор «HeidelbergCement») дозволила колективу дослідників: 1) створити окремі біогрупи 38 гарно квітучих ранньовесняних чагарників, у тому числі хвойних, на 5 ділянках; 2) результати проекту внести до навчально-методичних матеріалів дисципліни «Біорізноманіття і стратегія сталого розвитку»; 3) провести семінари зі збереження біорізноманіття з вчителями біології та екології, учнями та студентами закладів середньої і професійно-технічної освіти; 4) рекомендувати види для фітомеліорації інших кар'єрів компанії «ХайдельбергЦемент».
\end{abstract}

Ключові слова: збереження біорізноманіття, депозитарій «Рослини Червоної книги», екологічна стежка «Зелений шлях», чагарникові угруповання, Жовтокам'янський кар'єр.

Bcmyn. Збереження біорізноманіття є глобальною проблемою, яка має виняткове значення для такого антропогенно навантаженого регіону як Криворіжжя $[5,12,16,17]$. Руйнація природних ландшафтів внаслідок гірничо-видобувної діяльності зумовлює докорінну перебудову, трансформацію флори і фауни, зникнення або зменшення чисельності окремих видів або їхніх представників та становить 
серйозну загрозу біорізноманіттю $[13,21,25,31]$. У таких умовах створення окремих локусів (оселищ) існування видів флори і фауни 3 подальшим прогнозованим поширенням на прилеглі території кар'єру дозволить підвищити рівень біорізноманіття, а участь в реалізації таких дій - рівень екологічного виховання, фаховості та екологічної обізнаності учнівської, студентської молоді, пересічних громадян $[2,8,10,14]$. Реалізовані проекти стали продовженням фіторекультиваційних досліджень, вагомим сучасним практичним внеском у збереження біорізноманіття кафедри ботаніки та екології та неоціненим досвідом у реалізації подальших екологічних проектів.

Mema - проаналізувати результати участі викладачів i співробітників кафедри ботаніки та екології Криворізького державного педагогічного університету у міжнародних екологічних проектах, які були реалізовані у XXI столітті.

Матеріали та методи дослідженъ. Міжнародні екологічні проекти виконувалися в межах Жовтокам'янського кар'єра (Жовтокам'янське родовище цементної сировини). В адміністративному відношенні це родовище розташоване в Апостолівському районі Дніпропетровської області за 18-21 км на північний схід від районного центру і вузлової залізничної станції Апостолове Придніпровської залізниці. Жовтокам'янське родовище цементної сировини знаходиться на схилі південно-східної частини Придніпровської височини. У його геологічній будові вапняків і глин є сучасні (голоценові), плейстоценові і неогенові відклади, а також продукти кори вивітрювання докембрійських кристалічних порід.

Площа кар'єру, що розташований майже посередині родовища, складає близько 103 га. Режим роботи - цілорічний з безперервним робочим тижнем в 1 зміну по 12 годин. Кар'єр складається з 5-ти уступів: 1) грунтово-рослинний шар $(0,3-0,5 \mathrm{M}), 2)$ суглинки та жовті глини $(0,8-10,0$ м $), 3)$ червоно-бурі глини $(6,0-10,0$ м $), 4)$ вивітрений вапняк, некондиційний $(4,0-6,0$ м), 5) вапняк середньосарматичний $(7,0-9,0$ м). Ширина робочих майданчиків $30-35$ м, довжина кар'єру 1100 м. Глибина його на даний час складає від 0 до 40 м.

Дослідження проводилися у відпрацьовані частині кар'єра. Використовували загально-геоботанічні методи (рекогносцирувальний для загального зонування території та виділення перспективних для збільшення біорізноманіття зон, маршрутний для встановлення видового складу чагарників).

Рослини висаджували чагарники з грудкою або в контейнері у заздалегідь підготовлені ямки з гумусованим чорноземом і рясним поливом після посадки. 
Результати та $\ddot{\boldsymbol{\imath}} \boldsymbol{x}$ обговорення. У ХXI ст. викладачі і співробітники кафедри ботаніки та екології Криворізького державного педагогічного університету прийняли участь у двох міжнародних екологічних проектах. Перший проект - «Територія кар'єру як депозитарій для рідкісних рослин і основа для екологічної освіти (на прикладі Жовтокам'янського кар'єру)». Другий проект - «Створення чагарникових угруповань як нового місця існування для біоти кар'єру».

Міжнародний науковий проект

«Територія кар'єру як депозитарій для рідкісних рослин

i основа для екологічної освіти

(на прикладі Жовтокам'янсъкого кар'єру)»

Проект був виконаний в рамках програми The Quarry Life Award 2014 як складова конкурсу міжнародних досліджень 3 метою сприяння розвитку біорізноманіття в кар'єрах та освіти у природоохоронному напрямку. Організатор та фундатор конкурсу компанія «Хайдельберг-Цемент (HeidelbergCement)».

Команда проекту: к.б.н. Василь Савосько - керівник проекту (завідувач лабораторії «Екологія рослинності Кривбасу», Криворізький педагогічний інститут ДВНЗ «Криворізький національний університет»), к.б.н. Едуард Євтушенко (завідувач кафедри ботаніки та екології Криворізький педагогічний інститут ДВНЗ «Криворізький національний університет»), Юлія Копілева-Ромащенко (директор КПНЗ «Центр дитячої та юнацької творчості «Гармонія»»), Максим Квітко (асистент каф. зоології, фізіології і валеології Криворізький педагогічний інститут ДВНЗ «Криворізький національний університет»), Надія Аврамчук (методист КПНЗ «Центр дитячої та юнацької творчості «Гармонія»»), Юлія Попович (аспірант каф. ботаніки та екології Криворізький педагогічний інститут ДВНЗ «Криворізький національний університет»).

Meта проекту: розробити і впровадити природоохоронні технології використання частини території Жовтокам'янського кар'єру, де не проводяться гірничі роботи, для створення депозитарію «Рослини Червоної Книги» та проведення «Зелених уроків».

Завдання проекту: 1) провести еколого-ландшафтний аналіз території Жовтокам'янського кар'єру, що не використовується; 2) проаналізувати фіторізноманіття спонтанних вищих судинних рослин території Жовтокам'янського кар'єру, що не використовується; 3) створити депозитарій «Рослини Червоної книги» на території Жовтокам'янського кар'єру, що не використовується; 4) розробити 
Екологічну стежку «Зелений шлях» на території Жовтокам'янського кар'єру, що не використовується; 5) розглянути можливість подальшого використання результатів проекту у формуванні сталого розвитку регіону.

Результати проекту. Проект виконувався протягом вегетаційного сезону 2014 р. в межах території Жовтокам'янського кар'єру, що не використовується. Виробнича діяльність, унаслідок економічних і політичних причин, на цій території була зупинена орієнтовно у 1995 р. Рекультиваційні та інші природоохоронні роботи на неї не відбувалися. Надалі мало місце самовідновлення (регенерація) основних компонентів природних біогеосистем: рослинного та грунтового покривів (Рис. 1).

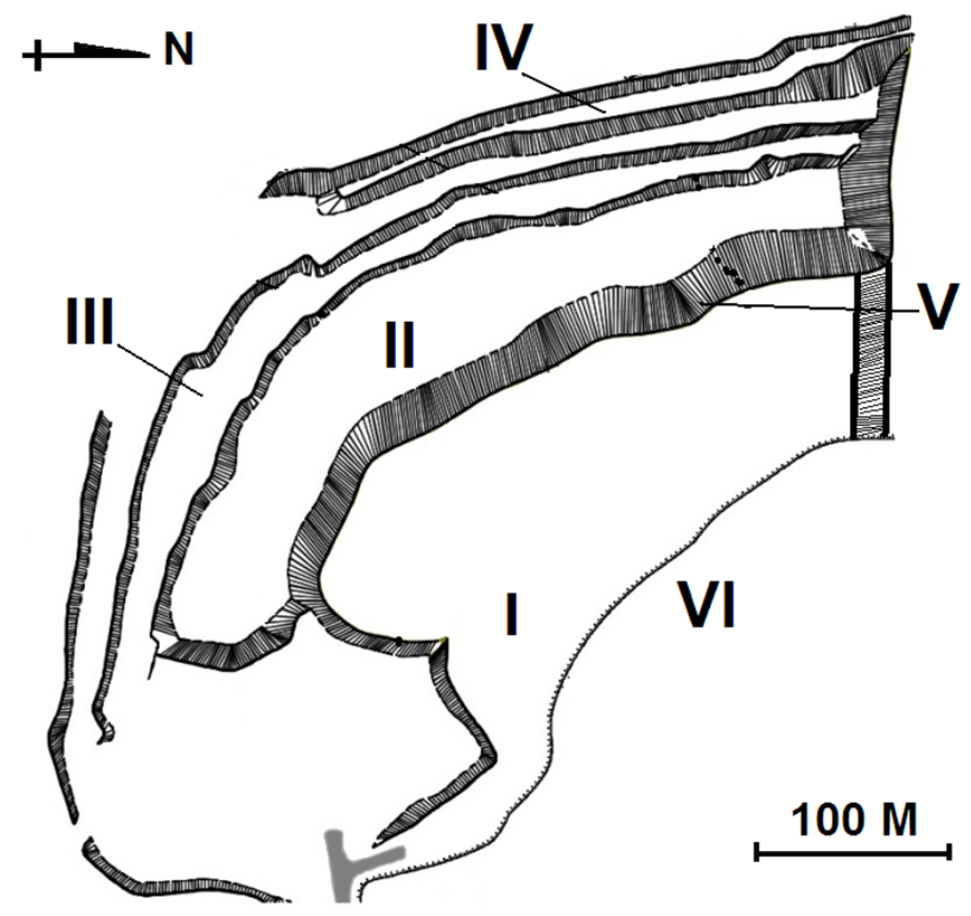

Рис. 1. Еколого-геоморфологічна характеристика Жовтокам'янського кар'єру, що не використовується Figure 1. Ecological and geomorphological characteristics of the Zhovtokamyansky quarry, part of which is not used I - днище кар'єру, II - перша берма, III - друга берма, IV - третя берма, $\mathrm{V}$ - технологічний розріз гірських порід, VI - свіжа відсипка 
Еколого-ландшафтний аналіз. Основними геоморфологічними елементами території Жовтокам'янського кар'єру, що не використовується, є: горизонтальні поверхні (днище, берми кар'єру), схилові поверхні (схили берм зі свіжою відсипкою), вертикальні поверхні (технологічний розріз гірських порід). Загальний стан цієї території є типовим для девастованих земель України та світу $[4,9,11,20]$.

На нашу думку, максимально сприятливі екологічні умови для росту і розвитку рослинного покриву мають місце на днищі кар'єру і другій бермі [22].

Фіторізноманіття. Попередні результати польових маршрутних досліджень рослинності території Жовтокам'янського кар'єру, що не використовується, дозволили встановити наявність у межах берм і днища 62 видів судинних трав'янистих рослин з 22 сімейств та 28 видів дерев і чагарників, які відносяться до 20 родів і 13 родин. Такі показники є співзвучними з результатами інших досліджень, які були проведені на інших девастованих землях Криворіжжя, України та світу $[3,4,16,23,24]$.

Депозитарій. Перспективним способом збереження рослинного біорізноманіття на території Жовтокам'янського кар'єру є створення депозитарію «Рослини Червоної книги». Під депозитарієм розуміється штучно створені біогрупи рідкісних рослин, які зростають та розвиваються без участі людини. При цьому передбачається, що з часом рослини депозитарію можуть бути використані для різних природоохоронних акцій (створення нових депозитаріїв, повернення у природу, формування насаджень на заповідних територіях). Як результат, «депозитарій» буде генерувати «відсотки».

При створенні депозитарію були використані три види трав'янистих рослин: ковила волосиста (Stipa capillata L.), Астрагал шерстистоквітковий (Astragalus dasyanthus Pall.), карагана скіфська (Caragana scythica (Com.) Pojark). Ці види занесені до Червоного списку Дніпропетровської області, Червоної книги України, Європейського та світового червоних списків [1], пристосовані до екологічних умов території кар'єру та мають неабияку певну етнографічну значущість (Табл. 1).

Депозитарій «Рослини Червоної книги» був закладений в травні 2014 р. на другій бермі території Жовтокам'янського кар'єру, що не використовується. Висаджено по 20 рослин кожного виду. При створенні депозитарію задля підвищення ефективності посадкових робіт нами використовувалися «Екомодулі» (Рис. 2). 
Таблиця 1. Характеристика видів депозитарію «Рослини Червоної книги»

Table 1. Characteristics of the species from Depository "Red List Plants"

\begin{tabular}{|c|c|c|c|c|}
\hline \multirow[b]{2}{*}{ Назва виду } & \multicolumn{4}{|c|}{ Природоохоронний статус виду } \\
\hline & $\begin{array}{c}\text { Червоний список } \\
\text { Дніпропетровської } \\
\text { області }\end{array}$ & $\begin{array}{l}\text { Червона } \\
\text { книга } \\
\text { України }\end{array}$ & $\begin{array}{c}\text { Європейський } \\
\text { Червоний } \\
\text { список }\end{array}$ & $\begin{array}{c}\text { Світовий } \\
\text { Червоний } \\
\text { список }\end{array}$ \\
\hline $\begin{array}{l}\text { Ковила } \\
\text { волосиста Stipa } \\
\text { capillata L. }\end{array}$ & 3 рідкісний & неоцінений & - & - \\
\hline $\begin{array}{l}\text { Астрагал } \\
\text { шерстисто- } \\
\text { квітковий } \\
\text { Astragalus } \\
\text { dasyanthus Pall. }\end{array}$ & 2 вразливий & вразливий & I невизначений & $\mathrm{R}$ рідкісний \\
\hline $\begin{array}{l}\text { Карагана } \\
\text { скіфська, } \\
\text { Caragana } \\
\text { scythica (Com.) } \\
\text { Pojark }\end{array}$ & 2 вразливий & вразливий & R рідкісний & - \\
\hline
\end{tabular}

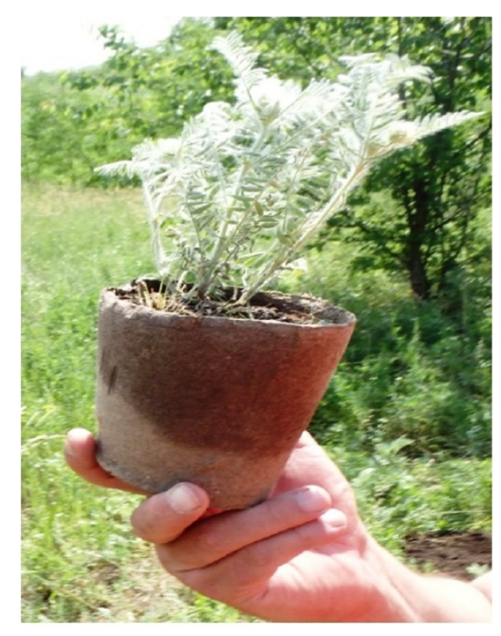

I

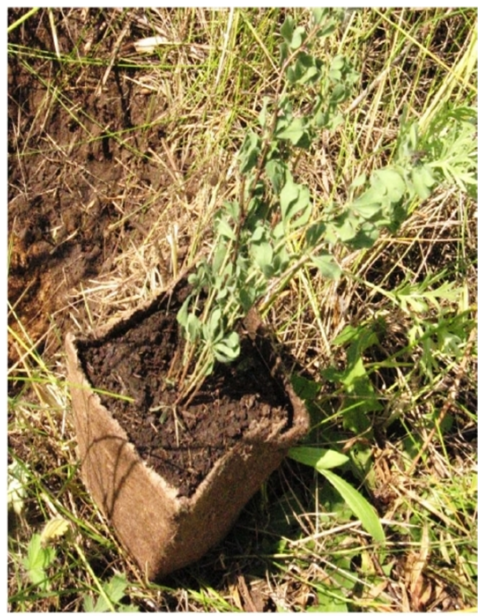

II

Рис. 2. Посадкові екомодулі

Figure 2. Ecomodules for planting

I - Астрагал шерстистоквітковий, II - Карагана скіфська 
Візуальні спостереження влітку та восени 2014 р. показали досить високий рівень успішності видів депозитарію: від 35 до $75 \%$. Остаточно оцінка перспективності депозитарію може бути виконана тільки в подальшому (Табл. 2). Висока природна приживлюваність використаних багаторічних рослин вселяє надію на успіх депозитарію.

\section{Таблиця 2. Попередні результати створення депозитарію «Рослини Червоної книги» \\ Table 2. Preliminary results in creating a depository "Red List Plants"}

\begin{tabular}{|l|c|c|}
\hline \multirow{2}{*}{ Назва виду } & \multicolumn{2}{|c|}{ Кількість живих екземплярів рослин, \% } \\
\cline { 2 - 3 } & 15 липня 2014 & 15 вересня 2014 \\
\hline $\begin{array}{l}\text { Ковила волосиста Stipa } \\
\text { capillata L. }\end{array}$ & $90-95$ & 85 \\
\hline $\begin{array}{l}\text { Acтрагал шерстистоквітковий } \\
\text { Astragalus dasyanthus Pall. }\end{array}$ & $80-90$ & 75 \\
\hline $\begin{array}{l}\text { Kapaгана cкiфська, Caragana } \\
\text { scythica (Com.) Pojark }\end{array}$ & $50-55$ & 35 \\
\hline
\end{tabular}

Екологічна стежка. У рамках проекту була розроблена Екологічна стежка «Зелений шлях», яка розміщена на території Жовтокам'янського кар'єру, що не використовується. Головна місія Екологічної стежки «Зелений шлях» - ознайомити її відвідувачів з унікальними й цікавими природними феноменами території Жовтокам'янського кар'єру. Екологічна стежка «Зелений шлях» складається із зупинок, які називають «Зеленою уроками»: 1) кар'єр, як техногенний об'єкт; 2) депозитарій рідкісних і зникаючих рослин; 3) фіторізноманіття трав'янистих рослин; 4) геологічне багатство кар'єру; 5) фіторізноманіття деревних рослин.

Екологічна стежка «Зелений шлях» розрахована на школярів 10-11 класів, студентів 1-2 курсів вищих навчальних закладів, а також на всіх любителів і цінителів природи. За розрахунками довжина маршруту становить 2,5 км, а його тривалість 90-120 хв.

Прикінцева інформація. Подальший розвиток проекту можливий у таких напрямах: 1) використання території Жовтокам'янського кар'єру як полігону для моніторингових досліджень процесів самовідновлення рослинного та грунтового покривів і як майданчик для проведення літніх польових практик студентів різних напрямків, 2) поповнення депозитарію «Рослини Червоної книги» новими екземплярами і видами 
рідкісних рослин, 3) поширення рослин депозитарію «Рослини Червоної книги» на прилеглі території, 4) використання Екологічної стежки «Зелений шлях» для екологічної освіти населення. Реалізація проекту у майбутньому буде сприяти просуванню ідей сталого розвитку. Як результат, природа обов'язково стане головним переможцем.

За рішенням журі Всеукраїнського етапу конкурсу The Quarry Life Award-2014 проект «Територія кар'єру як депозитарій для рідкісних рослин і основа для екологічної освіти (на прикладі Жовтокам'янського кар'єру)» та його команда були нагороджені дипломом третього ступеню.

\section{Міжнародний науковий проект \\ «Створення чагарникових угруповань як нового місия існування для біоти кар'єру»}

Проект був виконаний у рамках програми The Quarry Life Award 2018 як складова конкурсу міжнародних досліджень задля збереження біорізноманіття в кар'єрах та підвищення рівня екологічної освіти (громадський напрямок). Організатор та фундатор конкурсу компанія «ХайдельбергЦемент (HeidelbergCement)».

Учасники проекту: Євтушенко Едуард Олексійович - декан природничого факультету, кандидат біологічних наук, доцент кафедри ботаніки та екології, Комарова Ірина Олександрівна - асистент кафедри ботаніки та екології, Поздній Євген Валентинович - асистент кафедри ботаніки та екології, Брошко Євген Олегович - старший викладач кафедри зоології та методики навчання біології, кандидат біологічних наук, Федяніна Ірина Михайлівна - старший лаборант кафедри ботаніки та екології (Рис. 3).
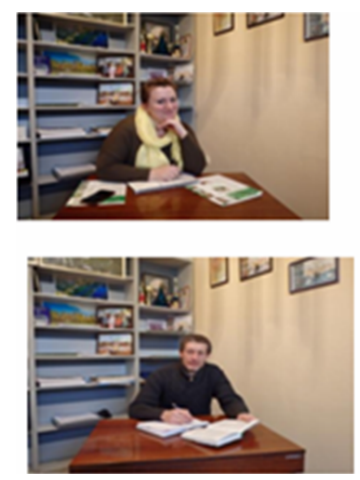
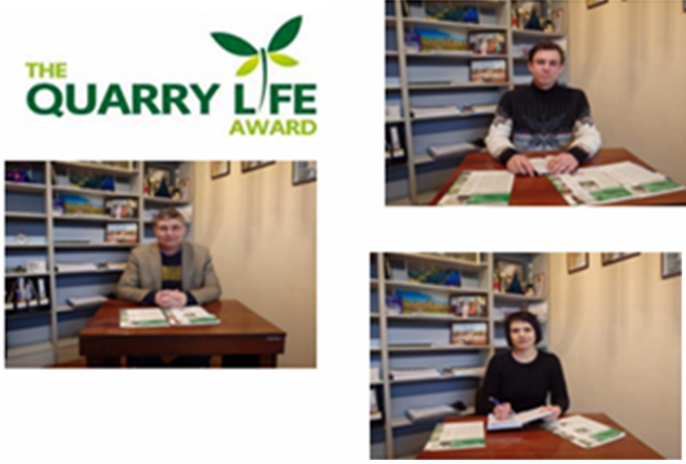

Рис. 3. Учасники проекту The Quarry Life Award 2018 Figure 3. Participants of the project The Quarry Life Award 2018 
Mета проекту: вирішення проблеми збереження біорізноманіття у науковому, освітньому та суспільно значимому аспектах.

Завдання проекту: 1) установити видовий склад, життєвість та поширення чагарникових рослин неробочої зони Жовтокам'янського кар'єру та виявити види, які збільшать біорізноманіття та є перспективними як осередки існування тварин; 2) дослідити екологічні умови та встановити ділянки придатні для приживання чагарникових рослин; 3) створити, на вільних від рослинності ділянках, біогрупи 3 природних або інтродукованих (гарно квітучих) чагарникових рослин та доповнити існуючі чагарникові угруповання видами, які не виявлені на території Жовтокам'янського кар'єру; 4) провести наукові екскурсії для студентів природничого факультету; 5) результати проекту внести до навчально-методичних матеріалів дисципліни «Біорізноманіття і стратегія сталого розвитку»; 6) провести екологічні семінари з вчителями біології та екології, учнями та студентами закладів середньої і професійно-технічної освіти; 7) хід виконання проекту висвітлити в друкованих, електронних і медійних засобах інформації.

Проект розрахований на отримання позитивного ефекту у формуванні екологічної свідомості, культури та фаховій підготовці школярів, студентів природничих спеціальностей, вчителів біології та екології шкіл, ліцеїв, професіонально технічних навчальних закладів, представників громадських організацій, пересічних громадян міста Кривий Ріг.

Результати проекту. Польові дослідження надали уявлення про різноманітність екологічних умов відпрацьованої частини кар'єру. Наявність достатнього зволоження стала критерієм визначення місця висадження рослин. Найкращі умови для чагарників спостерігаються на першій і другій бермі кар'єру. Обрані місця для розташування 5 ділянок (Рис. 4).

Ділянка № 1 знаходиться на 1 бермі, під бортом берми 2 у найбільш зволоженому місці, у заглибині якого в березні була тимчасова водойма. Шар осадових порід потужністю 15 см. Свіжий тип зволоження. Оточуюча рослинність - маслинка вузьколиста і шипшина.

Ділянка № 2 розташована на 2 бермі, під бортом берми 3 і під наметом робінії псевдоакації 10-15 річного віку в затінених умовах. Шар осадових порід потужністю 20 см. Сухуватий тип зволоження. Оточуюча рослинність - робінія псевдоакація і шипшина.

Ділянка № 3 розташована на 1 бермі на відстані 200 м від ділянки № 1 в напрямку перемички, під бортом берми 2, у найбільш зволоженому 
місці, у заглибині якого в березні було надмірне зволоження. Шар осадових порід потужністю 15 см. Свіжуватий тип зволоження. Оточуюча рослинність - маслинка вузьколиста, ясен зелений і шипшина.

Ділянка № 4 розташована на 1 бермі на відстані 100 м від ділянки № 3 в напрямку перемички, під бортом берми 2, у найбільш зволоженому місці, у заглибині якого в березні була тимчасова водойма. Шар осадових порід потужністю 10 см. Свіжий тип зволоження. Оточуюча рослинність - маслинка вузьколиста, ясен зелений і шипшина.

Ділянка №5 розташована на перемичці, що розділяє робочу i неробочу зони кар'єра, у найбільш зволоженому локалітеті (потускулі) геоморфогенного походження з шаром водотривких суглинків, Шар осадових порід потужністю 30 см. Свіжуватий тип зволоження. Оточуюча рослинність - робінія псевдоакація і шипшина.

На всіх ділянках у складі трав'янистої рослинності гігромезофіти та мезофіти очерет південний, куничник наземний.

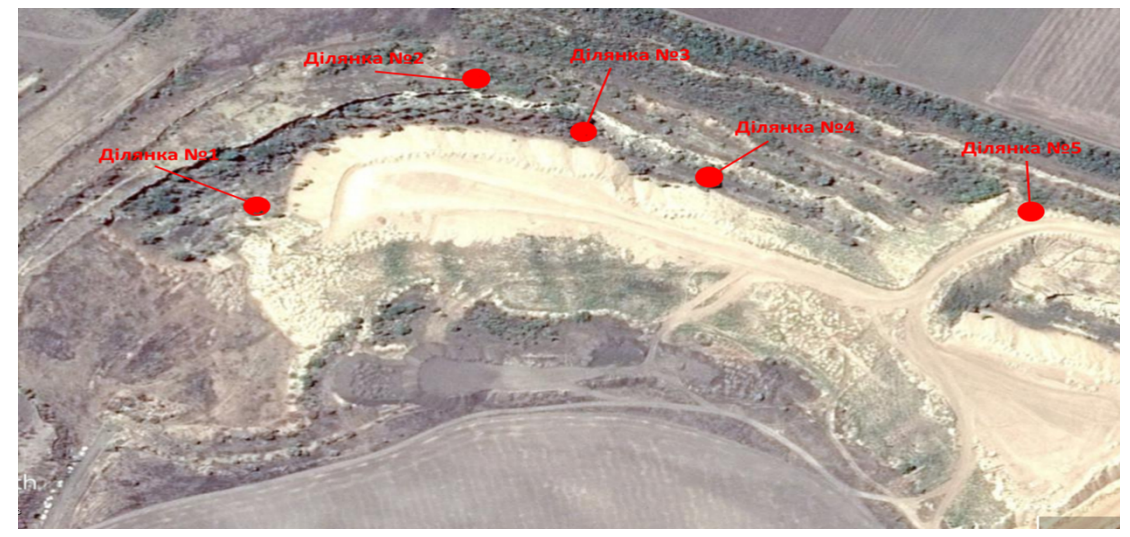

Рис. 4. Розміщення ділянок для створення біогруп чагарників Figure 4. The sites's location for the biogroups of shrubs planting

Створення насадженъ. Протягом квітня травня 2018 р. студенти природничого факультету здійснили екскурсійні виїзди до Жовтокам'янського кар'єру. На 5 підготовлених ділянках, під керівництвом викладачів-учасників проекту, 18 студентів біологів (у тому числі 5 іноземних студентів з Туркменістану) висадили чагарники різних видів, одержали практичні уміння і навички з проведення екскурсій, підготовки посадкового матеріалу та висадження рослин. Студенти отримали також теоретичні знання з проблеми збереження 
біорізноманіття у глобальному аспекті та можливості її вирішення на регіональному рівні. Керівник проекту Е. О. Євтушенко акцентував увагу студентів на важливості проведення заходів зі збереження біорізноманіття компанією «ХайдельбергЦемент Україна».

Загальна кількість висаджених чагарників була наступною: ялівець козацький (Juniperus sabina L.) -3 екз., сніжноягідник білий (Symphoricarpos albus (L.) Blake) - 5 екз., керрія японська (Kerria japonica (L.) Dc.) - 3 екз., бирючина звичайна (Ligustrum vulgare L.) 5 екз., бруслина європейська (Euonymus europaeus L.) - 4 екз., спірея японська (Spiraea japonica L.f.) - 3 екз., жимолость татарська (Lonicera tatarica L.) - 5 екз., бузок Звегинцова (Syringa sweginzowii Koehne \& Lindl.) -5 екз.

У травні 2018 р. учасники проекту Комарова Ірина та Поздній Євген здійснили черговий виїзд на кар'єр. Основна мета поїздки установлення табличок з назвами видів на ділянках, визначення стану чагарників. Установили, що на ділянках $3,4,5$ усі чагарники мають добрий стан, активно вегетують. На ділянці 2 не прижилася бруслина європейська і бузок Звегинцева, на ділянці 1 бузок Звегинцева. Висаджені чагарникові рослини функціонують відповідно своїй фенологічній фазі розвитку. Загалом, прижились на новому місці 90,9\% рослин (30 з 33 екземплярів). Найактивніше розвивається керія японська.

Екологічна освіта. Проведено екологічні семінари з учителями біології та екології, учнями та студентами закладів середньої і професійно-технічної освіти: 1) КЗОШ №7 - 02.03.2018 p. 2) КЗОШ № 94 - 05.03.2018 р., 3) презентація проекту на курсах підвищення кваліфікації вчителів хімії та біології. 14.03.2018р., 4) Жовтокам'янська школа. 18.05.18 p., 5) Дитячий оздоровчий табір «Сонячний» (с. Гурівка, Долинський район Кіровоградської області) - 09.06.2018 p., 03.08.201 р., екологічний тренінг «Планета моєї мрії» у Криворізькому професійному гірничо-технологічному ліцеї - 10.09.2018 p.

Був оголошений конкурс на формулювання слогану до логотипу (автор Є. В. Поздній) проекта «Створення чагарникових угруповань як нового місця існування для біоти кар'єру» (Creation of Shrub Groups as a New Habitat for Quarry's Biota). Журі зі складу учасників проекту оголосило переможцем Турського В'ячеслава - завідувача міжнародним відділом КДПУ - зі слоганом «Вдихни життя в кар'єр разом з компанією «ХайдельбергЦемент».

Створені електронні презентації «Екологічні характеристики чагарників Жовтокам'янського кар'єру» (автор Є. В. Поздній, відпові- 
дальний за флористичний напрямок) та «Тваринний світ Жовтокам'янського кар'єру» (Є. О. Брошко, відповідальний за фауністичний напрямок) використовуються у фаховій підготовці студентів біологів та екологів.

Результати проекту внесені до навчально-методичних матеріалів дисципліни «Біорізноманіття і стратегія сталого розвитку». У фаховій підготовці магістрів біологів значна увага приділяється природоохоронним проблемам і збереженню біорізноманіття. Результати реалізації проекту стали важливим практичним підгрунтям теоретичних розділів навчальної дисципліни.

Результати виконання проекту висвітлювалися на сайті компанії «ХайдельбергЦемент Україна», Криворізького державного педагогічного університету, в мережі Фейсбук та в Інстаграмі. До реалізації проекту були залучені директори криворізьких шкіл № 7 (Ю. С. Завалій), № 94 (С. М. Бородавка), Жовтокам’янської школи (Н. А. Гошина), ДОТ Сонячний (О.О. Крошка), директор Криворізького професійного гірничо-технологічного ліцею (колишнє ПТУ № 30) В. Г. Сиротюк, пресцентр КДПУ Авраменко, Д. Е. Шабанін.

Прикінцева інформація. На території непрацюючої частини кар'єру встановлено наявність на 41 виду рослин, що належать до 17 родин. Відбір чагарників для висадження здійснювався за критеріями посухостійкості, морозостійкості, життєздатності, періодів цвітіння та дозрівання плодів, трофності, можливості використання представниками фауни $[7,15,19,26,27]$. Відібрані 8 видів (сніжноягідник білий, керрія японська, бирючина звичайна, бруслина європейська, спірея японська, жимолость татарська, бузок Звегинцова, ялівець козацький) показали високий рівень приживання. Висаджені 33 чагарникові рослини у групах по $3-5$ видів (4-8 рослин на ділянці) на кожній з 5 ділянок, матимуть середовище перетворювальний вплив, сприятимуть поселенню нових видів трав'янистих рослин та збільшать фіторізноманіття території [6, 18, 28-30].

Загалом, для створення чагарникових угруповань як нового місця існування для біоти кар'єру можна рекомендувати усі види за виключенням бузка Звегинцева. Такий вид як керрія японська, $\epsilon$ оптимальним для висадження на несформованих грунтоподібних субстратах з різкими перепадами показників зволоження, оскільки $є$ гідроконтрастофілом

Установлено перебування на дослідних ділянках та поблизу їх (безпосереднє та опосередковане) 14 видів птахів (дрізд чорний, галка, сорока, фазан, коноплянка, щиглик, вівсянка садова, зеленяк, 
сорокопуд чорнолобий, синиця велика, горобець польовий, горлиця садова, соловейко, кам'янка звичайна), 1 виду земноводних (ропуха зелена), 1 виду плазунів (ящірка прудка), 1 виду ссавців (заєць сірий).

На підставі оцінки потенційних екологічних зв'язків та аналізу фауни прилеглих територій здійснено попередній прогноз появи на ділянках нових видів у майбутньому (птахів: шпак, жулан, омелюх, чикотень, кропив'янка сіра, яструб малий, сова вухата; ссавців: мишак лісовий, миша хатня, куниця кам'яна, тхір степовий, лисиця, ласка).

Таким чином, чагарникові види можуть бути рекомендовані для фітомеліорації інших кар'єрів компанії «ХайдельбергЦемент». Гарно квітучі ранньовесняні та декоративні види чагарникових рослин покращать естетичне сприйняття території і разом з чагарниковими видами природної флори стали середовищем проживання, харчування i розмноження різноманітних груп тваринного світу: паукоподібних, комах, плазунів, птахів і ссавців (шпак, жулан, омелюх, чикотень, кропив'янка сіра, яструб малий, сова вухата; ссавців: мишак лісовий, миша хатня, куниця кам'яна, тхір степовий, лисиця, ласка). Плоди та насіння ендо- та епізоохорно (представниками тваринного світу) уже цього року поширюватимуться на нові території, як кар'єру так і прилеглі до нього, збільшуючи їхнє біорізноманіття.

За рішенням журі Всеукраїнського етапу конкурсу The Quarry Life Award-2018 проект «Створення чагарникових угруповань як нового місця існування для біоти кар'єру» (на прикладі Жовтокам'янського кар'єру) та його команда були нагороджені дипломом першого ступеню.

Висновки. Підготовка і реалізація проектів зі збереження біорізноманіття провідними науковцями кафедри ботаніки та екології, за участі викладачів, лаборантів, аспірантів кафедри, викладача кафедри зоології та методики навчання біології, студентів природничого факультету КДПУ, викладача та вихованців ЦДЮТ «Гармонія» $є$ важливим етапом консолідації теоретичних знань і практичних зусиль зі збереження природного стану флори і фауни території відкритих гірничих розробок. Такі проекти покликані прискорити процеси самовідновлення рослинних угруповань у кар'єрах завдяки створенню депозитаріїв червонокнижних рослин, біогруп чагарникових рослин з видів зональної природної флори. Апробовані методи збереження та відновлення біорізноманіття території Жовтокам'янського кар'єру можуть бути використані у подальших пошуках ефективних засобів фітомеліорації та фіторекультивації порушених земель Криворіжжя. Виконання проекту сприяло фаховій підготовці студентів-біологів природничого факультету КДПУ, підвищенню кваліфікації вчителів 
біології та екології, екологічній обізнаності учнів шкіл, професійнотехнічних навчальних закладів Кривого Рогу, с. Жовтокам'янки, вихованців ЦДЮТ, пересічних громадян міста.

\section{Reference}

1. Andriienko, T. L. (compiler), \& Perehrym, M. M. (compiler) (2012). Ofitsiini pereliky rehionalno ridkisnykh roslyn administratyvnykh terytorii Ukrainy (dovidkove vydannia) [Official lists of regional rare plants of administrative territories of Ukraine (reference book)]. Alterpress. (in Ukraine).

2. Avera, B. N., Strahm, B.D., Burger, J. A., \& Zipper, C.E. (2015). Development of ecosystem structure and function on reforested surfacemined lands in the Central Appalachian Coal Basin of the United States. New Forests, 46, 683-702. https://doi.org/10.1007/s11056-015-9502-8

3. Berger, A., Brown, C., Kousky, C., \& Zeckhauser, R. (2011). The challenge of degraded environments: how common biases impair effective policy. Risk Analyses, 31 (9). https://doi.org/10.1111/j.15396924.2010.01477.x

4. Bielyk, Yu.V., Savosko, V.M., \& Lykholat, Yu. V. (2019). Taksonomichnyi sklad ta synantropna kharakterystyka derevnochaharnykovykh uhrupovan Petrovskoho vidvalu (Kryvorizhzhia). [Taxonomic composition and synanthropic characteristic of woody plant community on Petrovsky waste rock dumps (Kryvorizhzhya)]. Ekolohichnyi visnyk Kryvorizhzhia [Ecological Bulletin of Kryvyi Rih District], 4, 104-113. https://doi.org/10.31812/eco-bulletinkrd.v4i0.2565 (in Ukrainian).

5. Boiral, O., \& Heras-Saizarbitoria, I. (2017). Corporate commitment to biodiversity in mining and forestry: Identifying drivers from GRI reports. Journal of Cleaner Production, $162(20)$, 153-161. https://doi.org/10.1016/j.jclepro.2017.06.037

6. Byrne, C.F., Stormont, J.C., \& Stone, M. C. (2017). Soil water balance dynamics on reclaimed mine land in the southwestern United States. Journal of Arid Environments, 136, 28-37. https://doi.org/10.1016/j.jaridenv.2016.10.003

7. Ciria, C.S., Sanz, M., Carrasco, J., \& Ciria, P. (2019). Identification of arable marginal lands under rainfed conditions for bioenergy purposes in Spain. Sustainability, 11, 1833. https://doi.org/10.3390/su11071833 
8. Costanza, R. (2012). Ecosystem health and ecological engineering. Ecological Engineering, 45, 24-29. https://doi.org/10.1016/j.ecoleng .2012 .03 .023

9. Donald, A.F. (2017). Restoration ecology, resilience, and the axes of change. Annals of the Missouri Botanical Garden, 102, 201-216. https://doi.org/10.3417/2017006

10. Dorr de Quadros, P.D., Zhalnina, K., Davis-Richardson, A. G., Drew, J.C., Menezes, F.B., de O.Camargo, F. A., \& Triplett, E. W. (2016). Coal mining practices reduce the microbial biomass, richness and diversity of soil. Applied Soil Ecology, 98, 195-203. https://doi.org/10.1016/j.apsoil.2015.10.016

11. Dumroese, R. K., Williams, M. I., Stanturf, J. A., \& Clair, J. B. S. (2015). Considerations for restoring temperate forests of tomorrow: forest restoration, assisted migration, and bioengineering. New Forest, 45, 813-828. https://doi.org/10.1007/s11056-015-9504-6

12. Giam, X., Olden, J. D., \& Simberloff, D. (2018). Impact of coal mining on stream biodiversity in the US and its regulatory implications. Nature Sustainability, 1, 176-183. https://doi.org/10.1038/s41893-018-0048-6

13. Horáčková, M., Řehounková, K., \& Prach, K. (2015) Are seed and dispersal characteristics of plants capable of predicting colonization of postmining sites? Science and Pollution Research, 23 (14), 13617-13625. https://doi.org/10.1007/s11356-015-5415-5

14. Horodecki, P., \& Jagodziński, A. M. (2017). Tree species effects on litter decomposition in pure stands on afforested post-mining sites. Forest Ecology and Management, 406, 1-11. http://dx.doi.org/ 10.1016/j.foreco.2017.09.059

15. Macdonald, S. E., Landhäusser, S. M., Skousen, J., Franklin, J., Frouz, J., Hall, S., Jacobs, D. F., \& Quideau, S. (2015). Forest restoration following surface mining disturbance: challenges and solutions. New Forests, 46, 703-732. https://doi.org/10.1007/s11056-015-9506-4

16. Malenko, Ya. V. (2019). Spetsyfika spektriv vydiv davnoseredzemnomorskoi hrupy arealiv uhrupovan' roslyn tekhnohennykh ekotopiv [The specificity of spectra of ancient mediterranean species of the group of habitats of plant groups of Kryvyi Rih region technogenic ecotypes]. Ekolohichnyi visnyk Kryvorizhzhia [Ecological Bulletin of Kryvyi Rih District], 4, 22-40. https://doi.org/10.31812/eco-bulletin-krd.v4i0.2558 (in Ukrainian). 
17. Murguía, D. I., Bringezu, S., \& Schaldach, R. (2016). Global direct pressures on biodiversity by large-scale metal mining: Spatial distribution and implications for conservation. Journal of Environmental Management, $180(15), \quad 409-420$. https://doi.org/10.1016/j.jenvman.2016.05.040

18. Prach, K., \& Tolvanen, A. (2016). How can we restore biodiversity and ecosystem services in mining and industrial sites? Environmental Science and Pollution Research, 23, 13587-13590. https://doi.org/10.1007/s11356-016-7113-3

19. Řehounková, K., Čížek, L., Řehounek, J., Šebelíková, L., Tropek, R., Lencová, K., Bogusch, P., Marhoul, P., \& Máca, J. (2016). Additional disturbances as a beneficial tool for restoration of post-mining sites: a multi-taxa approach. Environmental Science and Pollution Research, 23 (14), 13745-137536. http://dx.doi.org/10.1007/s11356-016-6585-5

20. Rich, K., Ridealgh, M., West, S. E., Cinderby, S., \& Ashmore, M. (2015). Exploring the links between post-industrial landscape history and ecology through participatory methods. PLOS ONE, 10 (8), e0136522. https://doi.org/10.1371/journal.pone.0136522

21. Rolfe, J. (2000). Mining and biodiversity: rehabilitating coal mine sites. Policy, 16, 8-12.

22. Savosko, V. M., Lykholat, Y.V., Bielyk, Yu. V., \& Lykholat, T. Y. (2019). Ecological and geological determination of the initial pedogenesis on devastated lands in the Kryvyi Rih Iron Mining \& Metallurgical District (Ukraine). Journal of Geology, Geography and Geoecology, 28 (4), 738-746. https://doi.org/10.15421/111969

23. Savosko, V., Lykholat, Yu., Domshyna, K., \& Lykholat, T. (2018). Ekolohichna ta heolohichna zumovlenist poshyrennia derev i chaharnykiv na devastovanykh zemliakh Kryvorizhzhia [Ecological and geological determination of trees and shrubs' dispersal on the devastated lands at Kryvorizhya]. Journal of Geology, Geography and Geoecology, 27 (1), 116-130. https://doi.org/10.15421/111837 (in Ukraine).

24. Sonja, K. (2017). Sustainable post-mining land use: are closed metal mines abandoned or re-used space? Sustainability, 9 (10), 1705. https://doi.org/10.3390/su9101705

25. Sonter, L. J., Ali, S. H., \& Watson, James E. M. (2018). Mining and biodiversity: key issues and research needs in conservation science. Proceedings of the Royal Society B: Biological Sciences, 285 (1892), 20181926. https://doi.org/10.1098/rspb.2018.1926 
26. Vasquez, E. A., \& Sheley, R. L. (2018). Developing diverse, effective, and permanent plant communities on reclaimed surface coal mines: restoring ecosystem function. Journal American Society of Mining and Reclamation, 7 (1), 77-109. http://doi.org/10.21000/JASMR18010077

27. Waterhouse, B. R., Adair, K. L., Boyer, S., \& Wratten, S. D. (2014). Advanced mine restoration protocols facilitate early recovery of soil microbial biomass, activity and functional diversity. Basic Applied Ecology, 15, 599-606. https://doi.org/10.1016/j.baae.2014.09.001

28. Yevtushenko, E. O., \& Shanda, V.I. (2017). Kultur- ta ahrofitotsenoz: geneza poniattia, oznaky, struktura, funktsii [Cultural and agrophytocenosis: genesis of the concept, features, structure, functions]. In E. O. Yevtushenko (Eds.) \& V. M. Savosko (Eds.), Struktura ta rozvytok kulturfitotsenoziv Kryvorizhzhia [Structure and development of cultural phytocenoses at Kryvyi Rih District] (pp. 21-35). Dionat. (in Ukrainian).

29. Yevtushenko, E. O., Komarova, I. O., Pozdniy, Y.V., \& Kovalenko, L. H. (2019). Vplyv rozchynu bishofitu na reproduktyvnu sferu ambrozii polynolystoi v mezhakh prommaidanchyka PRAT INHZK [Influence of bischofite solution on the reproductive sphere of Ambrosia artemisiifolia within the limits of industrial ground of Private joint stock company "Inguletsky Ore mining and processing plant"]. Ekolohichnyi visnyk Kryvorizhzhia [Ecological Bulletin of Kryvyi Rih District], 4, 67-75. https://doi.org/10.31812/eco-bulletin-krd.v4i0.2561 (in Ukrainian).

30. Yevtushenko, E. O., Pozdnii, Y. V., Komarova, I. O., \& Kovalenko, L. H. (2019). Ekoloho-taksonomichna struktura derevno-chaharnykovykh roslynnykh uhrupovan promyslovykh maidanchykiv PrAT «Tsentralnyi hirnycho-zbahachuvalnyi kombinat» [Ecologycal-taxonomic structure of wood and shower plants of industrial pads of pjsc «central iron ore enrichment works»]. Pytannia stepovoho lisoznavstva ta lisovoi rekultyvatsii zemel [Issues of steppe forestry and forest reclamation of soils], 48, 47-61. https://doi.org/10.15421/441905 (in Ukrainian).

31. Zhang, Z.F., Bugosh, N., Tesfa, T., McDonald, M. J., \& Kretzmann, J.A. (2018). Conceptual model for hydrology-based geomorphic evapo transpiration covers for reclamation of mine. Journal American Society of Mining and Reclamation, $7(2)$, 61-88. http://doi.org/10.21000/JASMR18010077 


\title{
INTERNATIONAL ECOLOGICAL PROJECTS IN DEPARTMENTS OF BOTANY AND ECOLOGY AT KRYVYI RIH STATE PEDAGOGICAL UNSVERSITY
}

\author{
E. O. Yevtushenko, V. M. Savosko
}

Kryvyi Rih State Pedagogical Unsversity, Kryvyi Rih, Ukraine

\begin{abstract}
The results of participation of teachers and employees of department of botany and ecology at Kryvyii Rih State Pedagogical Unsversity in international ecological projects that were realized in XXI century were analyzed. The first international scientific project was named "Territory of quarry as a depositary for rare plants and basis for ecological education". This project was executed within the framework of the program The Quarry Life Award 2014 (organizer "HeidelbergCement"). The purpose of this project: to develop and implement environmental technologies for the use of part of the territory of the Zhovtokamyansky quarry, which is not working, to create a depository "Red Book Plants" and to conduct "Green Lessons". During realization of project his team (basis of that as made by teachers and employees of Department of Botany and Ecology) on Zhovtokamyansky had been implemented: 1) conducted the ecological and landscape analysis of territory, 2) investigated phitodiversity, 3) created the depositary of "Plant of the Red book", 4) worked out an ecological path the "Green way" and 5) offered directions of further development of project. The second international scientific project was named "Creation of Shrub Groups as a New Habitat for Quarry's Biota" This project was executed within the framework of the program The Quarry Life Award 2018 (organizer "HeidelbergCement"). The purpose of this project: to solving the problem of biodiversity conservation in scientific, educational and socially significant aspects. The results of this project were: 1 ) establishment of species composition, viability and distribution of shrub plants in the non-working part of the Zhovtokamyansky quarry, 2) identification of shrub species that will increase biodiversity and are promising as habitats for animals; 3) research of ecological conditions and identification of places for bush plantations; 4) creation of bushes; 5) organizing and conducting excursions for students of the Faculty of Natural Sciences; 6) introduction of research results into educational and methodical materials of disciplines; 7) conducting ecological seminars with teachers of biology and ecology, pupils and students of secondary and vocational education institutions; 8) clarification of all results of this project in print, electronic and media media.
\end{abstract}

Keywords: maintenance of biodiversity, depositary of "Plant of the Red book", ecological path the "Green way", shub groupments, Zhovtokamyansky quarry.

\section{Citation as:}

Yevtushenko, E. O., \& Savosko, V. M. (2020). Mizhnarodni ekolohichni proekty kafedry botaniky ta ekolohii Kryvorizkoho derzhavnoho pedahohichnoho universytetu [Iinternational ecological projects in

APA departments of botany and ecology at Kryvyi Rih State Pedagogical unsversity]. Ekolohichnyi visnyk Kryvorizhzhia [Ecological Bulletin of Kryvyi Rih District], 5, 60-77. https://doi.org/10.31812/ecobulletin-krd.v5i0.4354 ДСТУ кафедри ботаніки та екології Криворізького державного

Євтушенко Е. О., Савосько В.М. Міжнародні екологічні проекти 8302:2015 педагогічного університету. Екологічний Вісник Криворіжжся. 2020. Вип. 5. С. $60-77$. 